\title{
Pemetaan Paparan Panas pada Ruang Produksi PT. Pilar Kekar Plasindo Menggunakan Software Surfer 11
}

\author{
Fuky Prima Pradana ${ }^{1}$, Bambang Suhardi*2, dan Rahmaniyah Dwi Astuti ${ }^{3}$ \\ 1,2,3Program Studi Teknik Industri Universitas Sebelas Maret \\ ${ }^{*}$ Coresponden author email: bambangsuhardi@staff.uns.ac.id
}

\begin{abstract}
ABSTRAK
PT. Pilar Kekar Plasindo merupakan pabrik yang memproduksi kantong plastik dengan dua jenis produk plastik, yaitu plastik jenis Polypropylene (PP) dan Polyethylene (PE) dengan berbagai ukuran. Terdapat sepuluh area kerja di PT. Pilar Kekar Plasindo, dimana dalam proses produksinya memiliki risiko bahaya panas yang berasal dari lingkungan sekitar. Berdasarkan studi pendahuluan yang telah dilakukan diperoleh temperatur rata-rata pada ruang produksi PT. Pilar Kekar Plasindo sebesar $33,9^{\circ} \mathrm{C}$. Temperatur ini menyebabkan para pekerja di bagian produksi merasa tidak nyaman. Hal ini dibuktikan dengan hasil wawancara kepada para pekerja bagian produksi yang sering mengeluh dengan kondisi lingkungan kerja yang panas. Kondisi tersebut menyebabkan pekerja di bagian produksi cepat berkeringat, merasa kepanasan, tidak nyaman, cepat lelah, dan kurang fokus dalam bekerja. Pada ruang produksi dibutuhkan pemenuhan aspek kenyamanan termal untuk menunjang aktivitas didalamnya. Salah satu yang mempengaruhi kenyamanan termal adalah temperatur udara. Penelitian ini bertujuan untuk mengetahui kondisi lingkungan kerja berupa distribusi paparan panas pada ruang produksi PT. Pilar Kekar Plasindo melalui pemetaan menggunakan software surfer 11. Selain itu, untuk mengetahui tingkat kenyamanan termal pekerja sesuai dengan Keputusan Menteri Kesehatan No.1405/ MENKES/SK/XI/2002. Metode yang digunakan pada penelitian ini adalah pengukuran secara langsung berdasarkan SNI-16-7062-2004 dan ASHRAE 55. Waktu pengukuran dilakukan selama 6 hari kerja pada awal shift, tengah shift dan akhir shift berdasarkan SNI-16-7061-2004. Data yang diperoleh kemudian akan diolah menggunakan software surfer 11. Software surfer 11 digunakan untuk menggambarkan kondisi temperatur udara berupa peta kontur dari tiap area kerja pada ruang produksi PT. Pilar Kekar Plasindo, sehingga solusi yang diberikan diharapkan dapat memperbaiki lingkungan kerja kedepannya.
\end{abstract}

Kata kunci: Lingkungan kerja, Temperatur, Paparan panas, Kenyamanan termal, Software Surfer 11

\begin{abstract}
PT. Pilar Kekar Plasindo is a factory that produces plastic bags with two types of plastic products namely Polypropylene (PP) and Polyethylene (PE) types of various sizes. There are ten work areas in PT. Pilar Kekar Plasindo, which in its production process has the risk of heat hazard originating from the surrounding environment. Based on preliminary studies that have been obtained, the average temperature in the production room of PT. Pilar Kekar Plasindo at $33.9^{\circ} \mathrm{C}$. This temperature causes workers in the production department to feel uncomfortable. This is evidence by the results of interviews with production workers who often complain with the hot working environment. Workers in the production room of PT. Pilar Kekar Plasindo is often satisfied with a hot working environment. This condition can make production workers to sweating easily, feeling overheated, uncomfortable, exhausted, and lack focus in work. In the production space, it is necessary to fulfill the comfort aspects to support internal activities. One that affects thermal comfort is the air temperature. This study aims to determine the condition of the work environment in the form of heat exposure distribution in the production room of PT. Pilar Kekar Plasindo through mapping using software surfer 11. In addition, to determine the thermal comfort level of workers in accordance with Minister of Health Decree No.1405 / MENKES / SK / XI / 2002.. The method used in this study is SNI-16-7062-2004 and ASHRAE 55. The measurement time is carried out for 6 working days in the initial shift, middle shift and final shift based on SNI-16-7061-2004. The data obtained will then be processed using surfer software 11. Surfer software 11 is used to assess air condition consisting of contour maps of each work area in the production room of PT. Pilar Kekar Plasindo, so that the solution provided is expected to improve the work environment going forward.
\end{abstract}

Keywords: Work environment, Temperature, Heat exposure, Thermal comfort, Surfer 11 Software

Citation: Pradana, F.P., Suhardi, B., dan Astuti, R.D. (2020). Pemetaan Paparan Panas pada Ruang Produksi PT. Pilar Kekar Plasindo Menggunakan Software Surfer 11. Jurnal Ilmu Lingkungan, 18(1), 23-30, doi:10.14710/jil.18.1.23-30 


\section{Pendahuluan}

Lingkungan kerja adalah segala sesuatu yang bisa memberikan pengaruh baik atau buruk kepada organisasi atau perusahaan baik secara langsung maupun tidak langsung terhadap kinerja dan kepuasan kerja karyawan (Simanjuntak, 2003). Lingkungan kerja dirancang sedemikian rupa untuk menciptakan hubungan kerja yang mengikat antara pekerja dengan lingkungan kerjanya. Sedarmayanti (2011) menyatakan lingkungan kerja dikatakan baik apabila pekerja dapat enjalankan pekerjaan yang dibebankan dengan optimal, sehat, aman dan nyaman. Menurut Tarwaka (2004), lingkungan kerja dipengaruhi oleh 4 faktor, dimana faktor tersebut meliputi faktor fisik, faktor kimia, faktor psikologis, dan faktor biologis. Berdasarkan pendapat yang ada, maka dapat disimpulkan bahwa lingkungan kerja merupakan segala unsur - unsur yang berada disekitar pekerja dalam menjalankan tugasnya. Dimana lingkungan kerja tersebut dapat memberikan pengaruh terhadap kinerja para pekerja dalam menyelesaikan tugas - tugas yang diberikan.

OSHA (Occupational Safety \& Health Administration) menyatakan bahwa pekerjaan yang dilakukan pada temperatur yang tinggi, kelembaban yang tinggi, radiasi sumber panas, kontak fisik langsung dengan objek panas, atau aktifitas fisik yang berat memiliki potensi tinggi dalam menimbulkan tekanan panas (heat stress) terhadap pekerja yang melakukan aktivitas pekerjaan di area tersebut. Temperatur lingkungan di ruang kerja yang terlalu panas maupun dingin berbahaya terhadap kesehatan individu pekerja. Hal tersebut berdampak pada berkurangnya kenyamanan, gangguan penampilan fisik atau mental, sampai timbulnya gangguan kesehatan yang serius. Lingkungan kerja dengan temperatur yang panas akan menyebabkan pekerja merasa cepat lelah, berkurangnya performansi kerja, cepat mengantuk dan meningkatkan kemungkinan kesalahan kerja (Harrianto, 2010). Dalam penelitian Akimoto dkk (2010) menyatakan bahwa pekerja dengan suhu yang nyaman akan meningkatkan produktivitas dan kinerja. E. Somanathan dkk (2010) juga menyatakan temperatur tinggi dapat mengurangi output manufaktur dengan menurunkan produktivitas pekerja melalui tekanan panas.

Lingkungan kerja baik fisik maupun non fisik mempunyai pengaruh yang signifikan terhadap kinerja karyawan (Kamif dkk, 2016; Ningrum dkk, 2014). Lingkungan kerja yang panas pada ruang produksi mengakibatkan pekerja sering berkeringat, haus, konsentrasi cepat menurun, dan cenderung mudah lupa (Suhardi dkk, 2017). Salah satu gangguan yang dirasakan pekerja akibat lingkungan kerja terlalu panas dan bising berupa gangguan sakit kepala (Deb dkk, 2018). Selain itu dalam penelitian yang dilakukan Nurrahma dkk (2018) mengungkapkan bahwa lingkungan yang panas pada area kerja industri XYZ dapat menyebabkan pekerja mencuri curi waktu untuk mengurangi rasa kepanasan, hal ini dapat menghambat proses produksi dan menimbulkan potensi kerugian pada perusahaan.

PT. Pilar Kekar Plasindo merupakan sebuah perusahaan yang memproduksi kantong plastik dengan dua jenis plastik yaitu plastik jenis PP (Polypropylene) dan PE (Polyethylene) dengan berbagai ukuran. Pada Ruang produksi PT. Pilar Kekar Plasindo terdapat sepuluh area kerja, dimana dalam proses produksinya memiliki risiko bahaya panas yang berasal dari lingkungan sekitar. Berdasarkan studi pendahuluan yang telah dilakukan didapatkan temperatur rata - rata pada ruang produksi PT. Pilar Kekar Plasindo yaitu sebesar $33,97{ }^{\circ} \mathrm{C}$, temperatur tersebut dinyatakan kurang nyaman untuk pekerja. Haryono dan Subaris (2007) menyatakan bahwa udara atau temperatur yang dianggap nyaman bagi orang Indonesia adalah $24^{\circ} \mathrm{C}$ sampai $26^{\circ} \mathrm{C}$ dengan selisih suhu di dalam (tubuh) dan suhu di luar (ruangan) tidak boleh lebih dari $5{ }^{\circ} \mathrm{C}$. Keputusan Menteri Kesehatan No.1405/ MENKES/SK/XI/2002 tentang Persyaratan Kesehatan lingkungan Kerja Perkantoran dan Industri ditempat kerja dirasakan nyaman dan dapat diterima yaitu sebesar $18^{\circ} \mathrm{C}$ sampai $28^{\circ} \mathrm{C}$.

Hasil pengukuran temperatur rata-rata di ruang produksi PT. Pilar Kekar Plasindo diperoleh $33,9^{\circ} \mathrm{C}$. Temperatur rata-rata di ruang produksi lebih tinggi dibandingkan persyaratan kesehatan lingkungan kerja perkantoran dan industri berdasarkan Keputusan Menteri Kesehatan No. 1405/MENKES/SK/XI/2002. Kondisi lingkungan kerja yang panas ini menyebabkan pekerja merasa tidak nyaman. Hasil wawancara menunjukkan bahwa pekerja bagian produksi merasa kepanasan, cepat lelah, mengeluarkan keringat yang banyak, dan kurang fokus dalam bekerja. Banyak pekerja yang mencuri waktu untuk istirahat sejenak, sehingga waktu produksi banyak yang hilang. Hal ini mengakibatkan target produksi tidak terpenuhi. Oleh karena itu perlu dilakukan perbaikan temperatur di ruang produksi PT. Pilar Kekar Plasindo. Untuk memudahkan dalam melakukan perbaikan lingkungan kerja, maka pada penelitian ini dilakukan pembuatan peta kontur temperatur pada ruang produksi PT. Pilar Kekar Plasindo menggunakan software surfer.

\section{Metode Penelitian}

Metode yang digunakan dalam penelitian ini adalah metode survei lapangan dengan sistem grid dan pengukuran langsung yang kemudian akan dianalisis secara deskriptif. Alat yang digunakan 
dalam pengukuran temperatur udara yaitu CEM DT88804 in 1 Multifunction Environment Meter pada fasilitas temperature meter. Dalam penelitian ini, pengukuran dilakukan selama enam hari mulai pukul 08.00 hingga pukul 16.00 WIB. Dimana interval pengukuran berdasarkan SNI-16-7061-2004 yaitu pukul 08.00 WIB mewakili awal shift, pukul 13.00 WIB mewakili tengah shift, dan 16.00 WIB mewakili akhir shift. Titik pengukuran temperatur udara dilakukan berdasarkan SNI 16-7062-2004. Tingkat gradien pengukuran berdasarkan standar pengukuran ASHRAE dengan ketinggian 0,1m; 1,1m; dan 1,7m.

Software yang digunakan dalam pembuatan peta kontur adalah Software Surfer 11. Dengan software surfer 11 dapat diketahui zona terekstrim pada peta kontur (Pramesti dkk, 2018). Dimana pada penelitian ini, yang dimaksudkan zona terekstrim berupa zona temperatur udara paling tinggi. Untuk membuat peta kontur, data yang digunakan harus dalam bentuk grid. Grid merupakan serangkaian garis vertikal dan horisontal yang terdapat pada software surfer 11 berbentuk segi empat yang digunakan sebagai dasar pembentukan peta kontur maupun surface tiga dimensi (Winata dan Hartyanto, 2013). Adapun langkah - langkah dalam pembuatan peta kontur temperatur udara menggunakan software surfer 11 dapat dilihat pada diagram alir berikut.

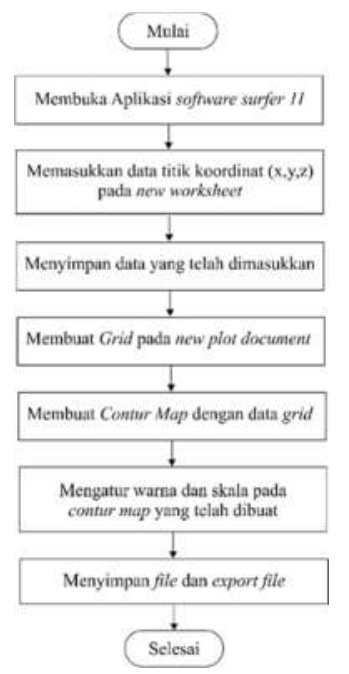

Gambar 1. Diagram Alir Pembuatan Peta Kontur dengan Software Surfer 11

\section{Hasil dan Pembahasan}

\subsection{Titik koordinat pengukuran}

Pada ruang produksi PT. Pilar Kekar Plasindo memiliki 10 area kerja meliputi area cutting plastik digital, cutting plastik manual, gudang barang jadi, inspeksi, pembuatan plastik PP besar, pembuatan plastik PP kecil, gudang material serta pada gedung 2 meliputi pembuatan plastik PE 1, pembuatan plastik PE 2, dan gudang sementara PE. Adapun ukuran tiap area dapat dilihat pada tabel 1.

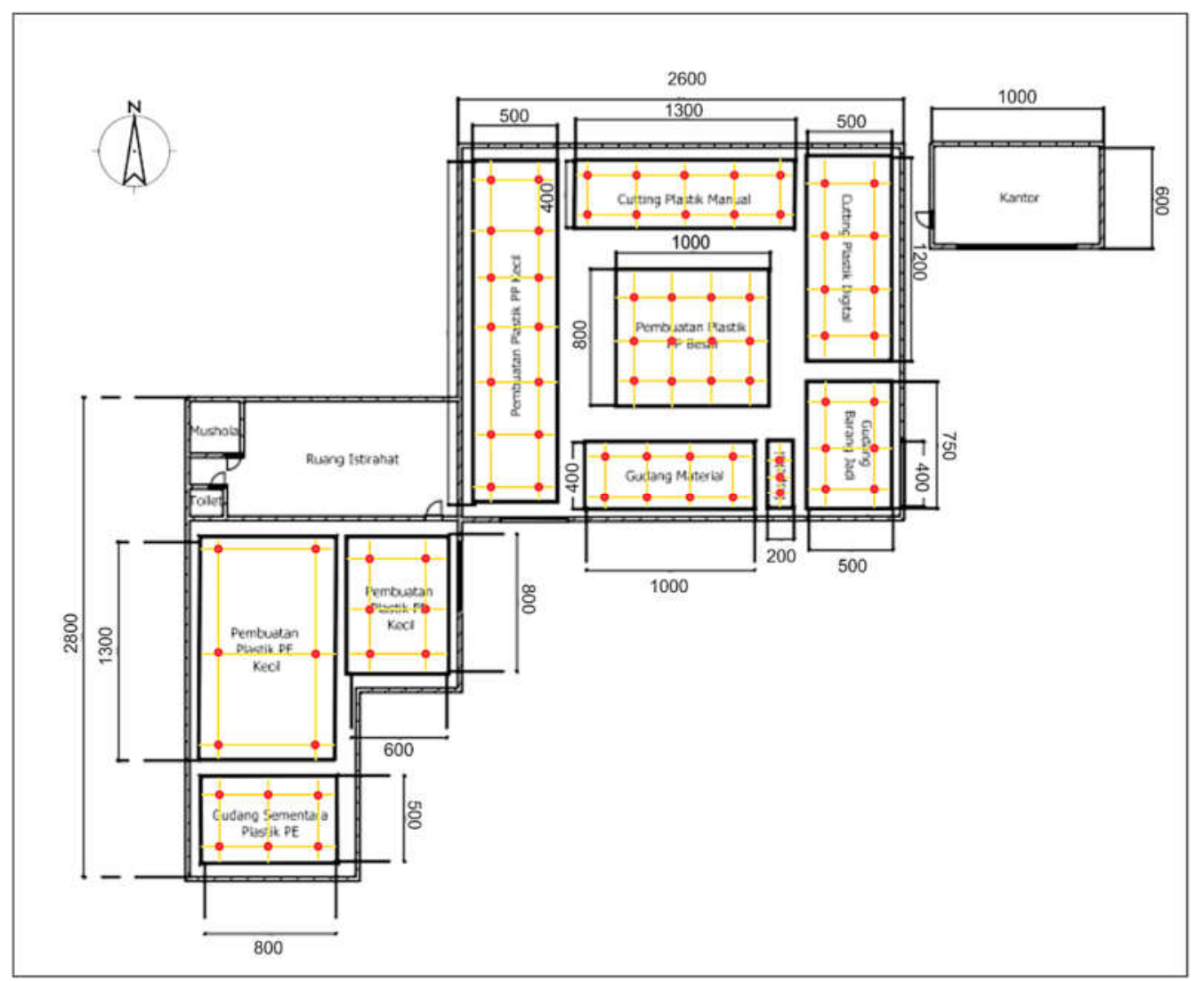

Gambar 2. Titik Koordinat Pengukuran Ruang Produksi PT. Pilar Kekar Plasindo 
Tabel 1. Luas Lantai Produksi PT. Pilar Kekar Plasindo

\begin{tabular}{ccccc}
\hline \hline \multirow{2}{*}{ No } & \multirow{2}{*}{ Stasiun Kerja } & \multicolumn{2}{c}{ Ukuran Stasiun Kerja } & \multirow{2}{*}{ Luas $\left(\mathrm{m}^{2}\right)$} \\
\cline { 3 - 4 } & Cutting plastik digital & 12 & Lebar $(\mathrm{m})$ & \\
\hline 1 & Cutting plastik manual & 13 & 4 & 60 \\
2 & Gudang barang jadi & 7,5 & 5 & 52 \\
3 & Inspeksi & 4 & 2 & 87,5 \\
4 & 10 & 8 & 80 \\
5 & Pembuatan plastik PP besar & 20 & 5 & 100 \\
6 & Pembuatan plastik PP kecil & 10 & 4 & 40 \\
7 & Gudang material & 8 & 6 & 48 \\
8 & Pembuatan plastik PE 1 & 13 & 8 & 104 \\
9 & Pembuatan plastik PE 2 & 8 & 5 & 40 \\
10 & Gudangsementara PE & Total Luas Lantai Produksi & 569,5 \\
\hline \multicolumn{5}{c}{}
\end{tabular}

Setelah didapatkan ukuran tiap area, maka dapat dibuat grid untuk menentukan titik koordinat pada tiap area berdasarkan SNI 16-7062-2004. Adapun titik koordinat pada masing-masing area dapat dilihat pada gambar 2 .

\subsection{Peta kontur temperatur udara}

Pengambilan data temperatur udara dilakukan berdasarakan titik korrdinat pengukuran yang telah dibuat. Setelah dilakukan pengukuran selama 6 hari yang telah ditentukan sebelumya, maka didapatkan nilai rata - rata temperatur udara pada tiap titik koordinatnya. Kemudian dilakukan pembuatan peta kontur temperatur udara dengan menggunakan software surfer 11 pada area cutting plastik digital, cutting plastik manual, gudang barang jadi, inspeksi, pembuatan plastik PP besar, pembuatan plastik PP kecil, gudang material serta pada gedung 2 meliputi pembuatan plastik PE 1, pembuatan plastik PE 2, dan gudang sementara PE. Peta kontur tersebut dapat dilihat pada gambar 3 hingga gambar 13 .

Berdasarkan hasil peta kontur temperatur udara pada area cutting plastik digital suhu tertinggi terletak pada titik koordinat $(100,450)$ sebesar $34,28{ }^{\circ} \mathrm{C}$, dan suhu terendah terletak pada titik koordinat $(400,150)$ sebesar $34,14{ }^{\circ} \mathrm{C}$.

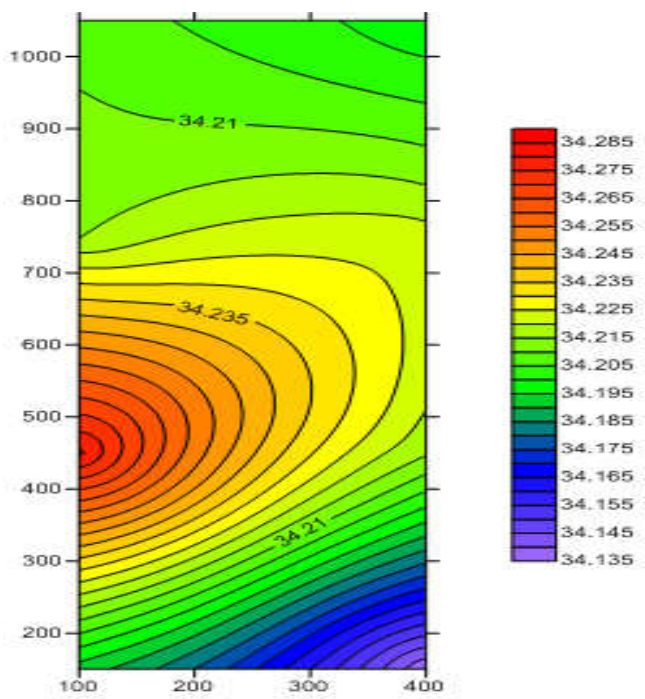

Gambar 3. Peta Kontur Temperatur Udara pada Area Cutting Plastik Digital

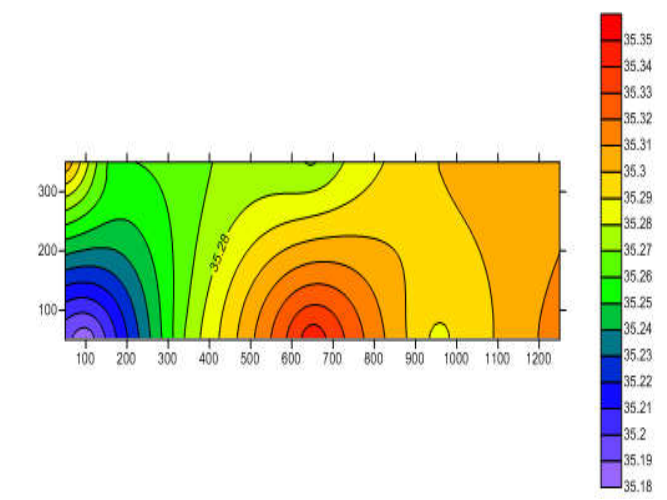

Gambar 4. Peta Kontur Temperatur Udara pada Area Cutting Plastik Manual

Berdasarkan hasil peta kontur temperatur udara pada area cutting plastik manual suhu tertinggi terletak pada titik koordinat $(650,50)$ sebesar 35,35 ${ }^{0} \mathrm{C}$, dan suhu terendah terletak pada titik koordinat $(100,50)$ sebesar $35,18^{\circ} \mathrm{C}$.

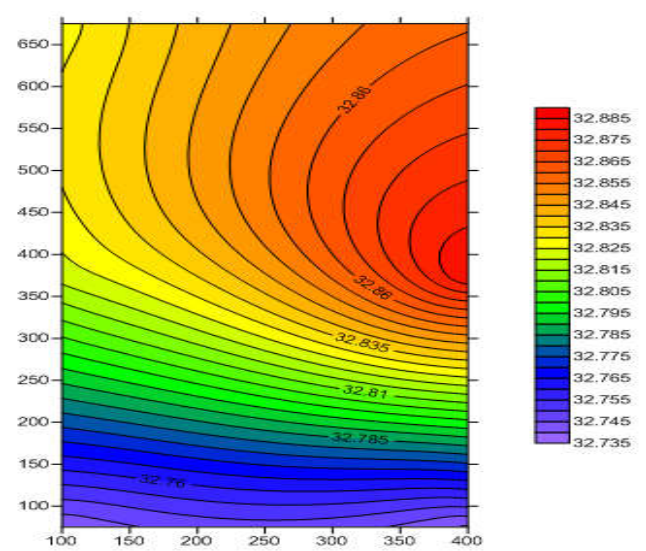

Gambar 5. Peta Kontur Temperatur Udara pada Area Gudang Barang Jadi

Berdasarkan hasil peta kontur temperatur udara pada area gudang barang jadi suhu tertinggi terletak pada titik koordinat $(400,375)$ sebesar $32,89{ }^{\circ} \mathrm{C}$, dan suhu terendah terletak pada titik koordinat $(100,75)$ sebesar $32,74{ }^{\circ} \mathrm{C}$.

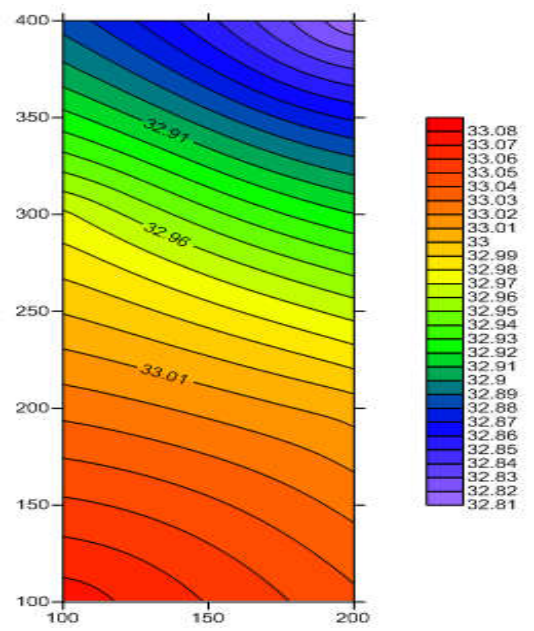

Gambar 6. Peta Kontur Temperatur Udara pada Area Inspeksi 
Berdasarkan hasil peta kontur temperatur udara pada area inspeksi suhu tertinggi terletak pada titik koordinat $(100,100)$ sebesar $33,08{ }^{\circ} \mathrm{C}$, dan suhu terendah terletak pada titik koordinat $(100,400)$ sebesar $32,81^{\circ} \mathrm{C}$.

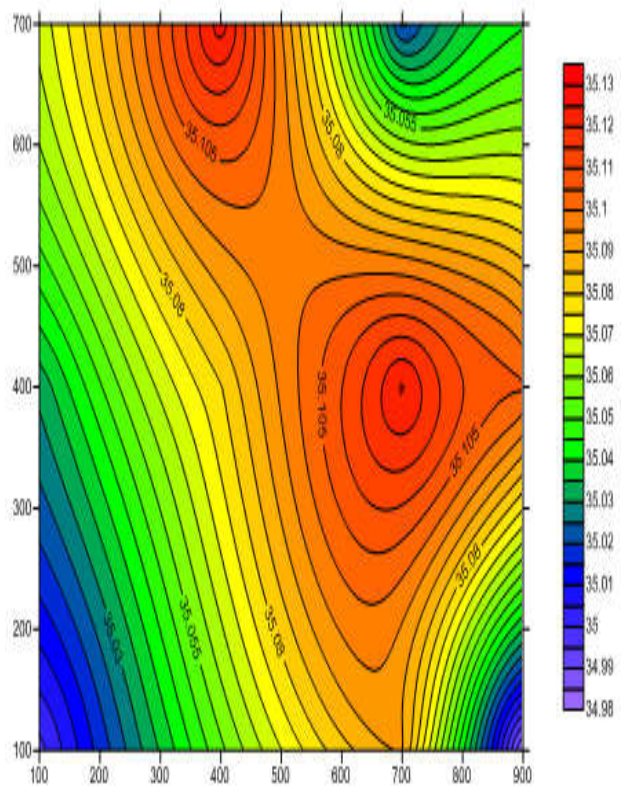

Gambar 7. Peta Kontur Temperatur Udara pada Area Pembuatan Plastik PP Besar

Berdasarkan hasil peta kontur temperatur udara pada area pembuatan plastik PP besar suhu tertinggi terletak pada titik koordinat $(700,400)$ sebesar 35,13 ${ }^{0} \mathrm{C}$, dan suhu terendah terletak pada titik koordinat $(900,100)$ sebesar $34,98^{\circ} \mathrm{C}$.

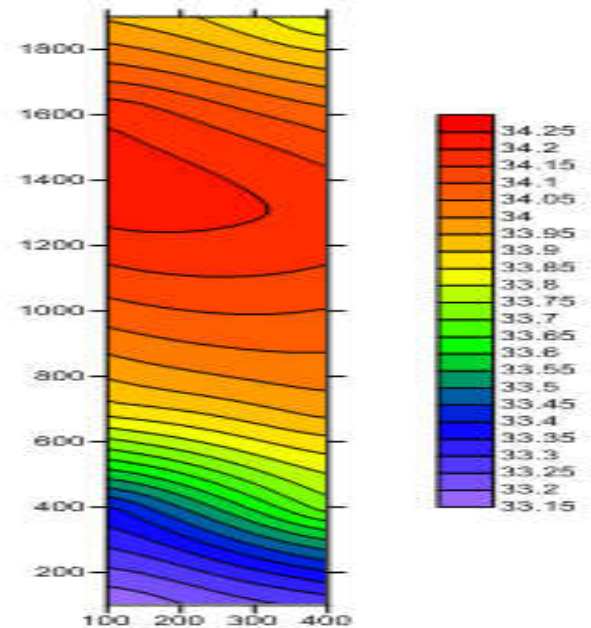

Gambar 8. Peta Kontur Temperatur Udara pada Area Pembuatan Plastik PP Kecil

Berdasarkan hasil peta kontur temperatur udara pada area pembuatan plastik PP kecil suhu tertinggi terletak pada titik koordinat $(100,1300)$ sebesar $34,22{ }^{\circ} \mathrm{C}$, dan suhu terendah terletak pada titik koordinat $(100,100)$ sebesar $33,15^{\circ} \mathrm{C}$.

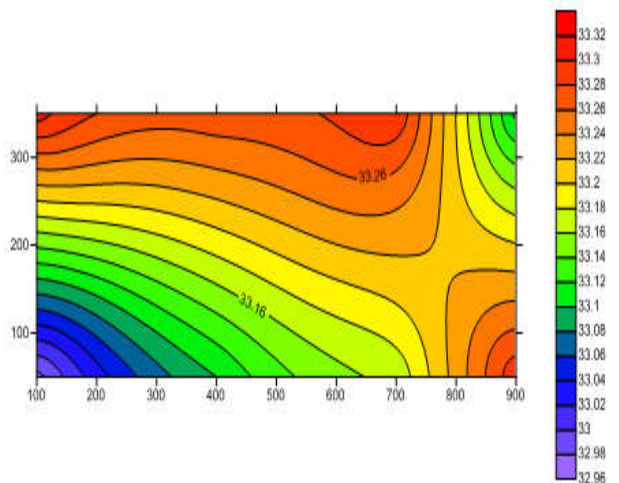

Gambar 9. Peta Kontur Temperatur Udara pada Area Gudang Material

Berdasarkan hasil peta kontur temperatur udara pada area gudang material suhu tertinggi terletak pada titik koordinat $(100,350)$ sebesar $33,31{ }^{\circ} \mathrm{C}$, dan suhu terendah terletak pada titik koordinat $(900,350)$ sebesar $33,09{ }^{\circ} \mathrm{C}$.

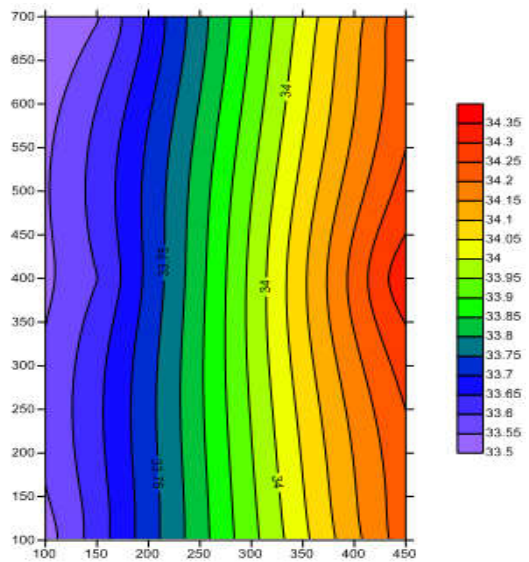

Gambar 10. Peta Kontur Temperatur Udara pada Area Pembuatan Plastik PE 1

Berdasarkan hasil peta kontur temperatur udara pada area pembuatan plastik PE 1 suhu tertinggi terletak pada titik koordinat $(450,400)$ sebesar 34,34 ${ }^{0} \mathrm{C}$, dan suhu terendah terletak pada titik koordinat $(100,100)$ sebesar $33,53{ }^{\circ} \mathrm{C}$.

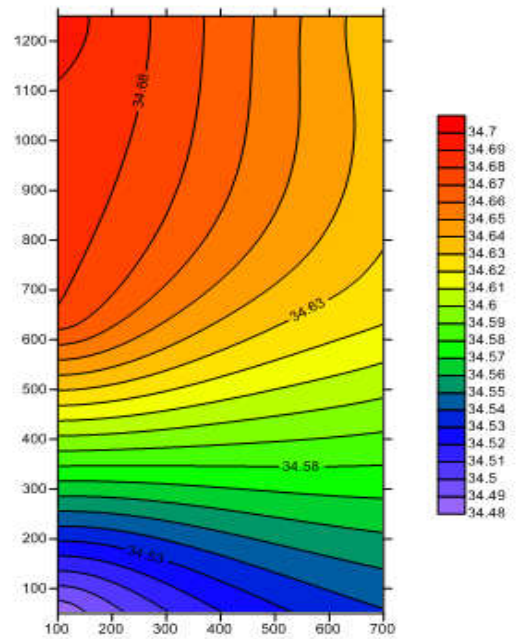

Gambar 11. Peta Kontur Temperatur Udara pada Area Pembuatan Plastik PE 2 
Berdasarkan hasil peta kontur temperatur udara pada area pembuatan plastik PE 2 suhu tertinggi terletak pada titik koordinat $(100,650)$ sebesar 34,68 ${ }^{0} \mathrm{C}$, dan suhu terendah terletak pada titik koordinat $(100,50)$ sebesar $34,48{ }^{\circ} \mathrm{C}$.

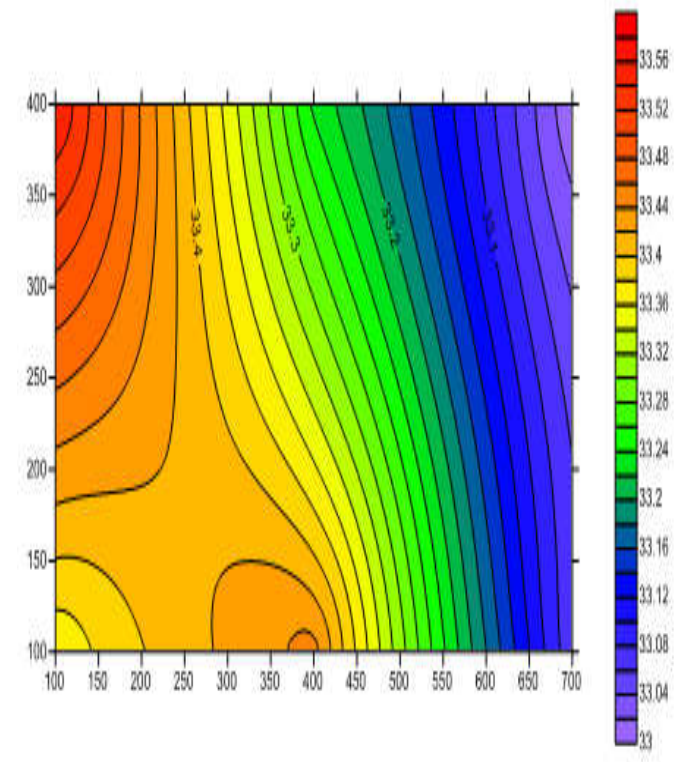

Gambar 12. Peta Kontur Temperatur Udara pada Area Gudang Sementara Plastik PE

Berdasarkan hasil peta kontur temperatur udara pada area sementara plastik PE suhu tertinggi terletak pada titik koordinat $(100,400)$ sebesar $33,56{ }^{\circ} \mathrm{C}$, dan suhu terendah terletak pada titik koordinat $(700,400)$ sebesar $33,00^{\circ} \mathrm{C}$.

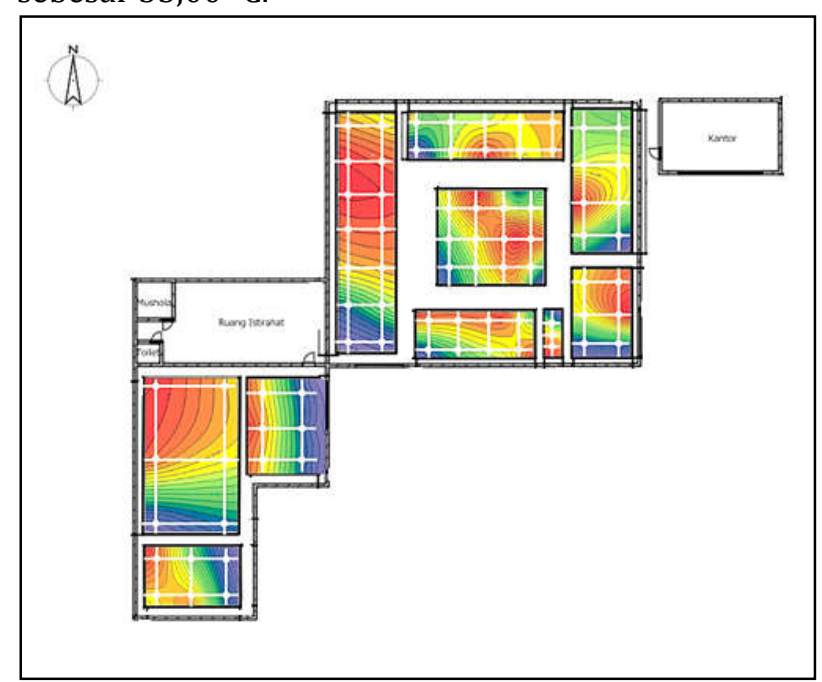

Gambar 13. Peta Kontur Temperatur Udara pada Ruang Produksi PT. Pilar Kekar Plasindo

Berdasarkan peta kontur ke 10 area yang telah dibuat dengan menggunakan software surfer 11 dapat dilihat bahwa temperatur udara tertinggi ditunjukkan dengan warna merah dan temperatur terendah ditunjukkan dengan warna ungu (Gambar 13). Dari hasil pengukuran rata - rata selama 6 hari pada tiap area produksi diketahui bahwa stasiun cutting plastik manual memiliki nilai temperatur paling tinggi yaitu sebesar 35,35 ${ }^{\circ} \mathrm{C}$. Hal ini disebabkan letak stasiun cutting plastik manual berada di bagian belakang dan jauh dari pintu masuk. Selain itu bangunan PT. Pilar Kekar Plasindo tidak memiliki sirkulasi udara yang baik dalam hal ini ventilasi/bukaan tidak ada. Sehingga pertukaran udara dalam bangunan tidak lancar. Udara panas dalam bangunan terperangkap tidak bisa keluar untuk digantikan udara segar dari luar bangunan. Purwanto (2006) menyatakan bahwa bentukan atap bangunan yang tidak memiliki sirkulasi udara di dalam atap akan memberikan kontribusi panas di ruang dibawahnya yang mempengaruhi kenyamanan termal. Sukawi dkk (2013) menyatakan udara luar yang lebih dingin akan masuk ke dalam bangunan menggantikan tempat yang ditinggalkan udara yang panas tadi dengan catatan bangunan tersebut mempunyai ventilasi yang cukup. Susanti dan Aulia (2013) menyatakan ada dua faktor yang mempengaruhi kenyamanan, yaitu: arah bangunan yang menghadap atau membelakangi sinar matahari dan letak maupun jumlah ventilasi yang terkait dengan pertukaran udara.

Stasiun cutting plastik manual memiliki 14 mesin yang memicu terjadinya paparan panas dari aktivitas mesin tersebut. Lokasi stasiun cutting plastik manual dikelilingi 3 stasiun lain yaitu stasiun cutting plastik digital, pembuatan plastik PP besar, dan pembuatan plastik PP kecil. Ketiga stasiun ini dalam proses produksinya menggunakan mesin sehingga aktivitas mesin tersebut dapat menambah paparan panas pada area stasiun cutting plastik manual. Paparan panas yang disebabkan oleh beroperasinya mesin pada ketiga stasiun tersebut menambah kenaikan temperatur sebesar $1^{\circ} \mathrm{C}$.

Faktor lain yang menyebabkan ruang produksi PT. Pilar Kekar Plasindo panas karena pemakaian atap bangunan pabrik menggunakan asbes. Asbes merupakan material yang menyerap panas sinar matahari. Warna dinding bangunan secara psikologis juga memberikan kesan panas pada para pekerja. Apalagi warna dinding bangunan pabrik adalah abu abu. Warna abu abu memberikan kesan panas.

Area gudang barang jadi memiliki temperatur paling rendah yaitu sebesar $32,81{ }^{\circ} \mathrm{C}$. Hal ini terjadi karena lokasi gudang barang jadi dekat dengan pintu utama yang selalu terbuka. Sehingga sirkulasi udara di area ini lebih lancar dibandingkan area yang lain. Terjadi pertukaran udara panas di dalam ruangan dengan udara dingin dari luar. Hal ini sesuai dengan penelitian-penelitian sebelumnya (Sukawi dkk, 2013; Susanti dan Aulia, 2013). Selain itu, pada stasiun gudang barang jadi tidak terdapat mesin, sehingga tidak mendapatkan paparan panas dari aktivitas mesin produksi.

Dari ke 10 area yang ada pada ruang produksi PT. Pilar Kekar Plasindo rata-rata pengukuran temperatur terbesar terjadi pada siang hari. 
Sedangkan nilai rata-rata pengukuran temperatur terkecil terjadi pada pagi hari.

Perbedaan temperatur antara pagi hari dan siang hari disebabkan 2 faktor utama, yaitu ketebalan atmosfer yang harus dilintasi sinar matahari sebelum sampai ke permukaan bumi dan perbedaan kerapatan sinar akibat perbedaan sudut datangnya sinar matahari. Atmosfer memilki ketebalan yang relatif sama. Pagi hari arah datangnya sinar matahari miring, maka sinar matahari perlu melintasi atmosfer yang lebih tebal daripada saat siang hari. Semakin tebal atmosfer yang dilintasi, maka semakin banyak energi dari matahari yang diserap oleh atmosfer dan semakin sedikit energi yang sampai ke permukaan bumi. Akibatnya saat pagi hari temperatur lebih rendah dibandingkan siang hari

Pagi hari arah datangnya sinar matahari miring, sinar matahari dengan jumlah yang sama akan tersebar pada daerah yang lebih luas. Sedangkan pada siang hari, sinar matahari yang sama akan terkonsentrasi pada luas daerah yang lebih kecil. Akibatnya siang hari lebih panas dibandingkan pagi hari.

Adapun rata - rata temperatur udara selama 6 hari pada tiap area dapat dilihat pada tabel 2 .

Tabel 2. Rata - rata Temperatur Udara Tiap Area

\begin{tabular}{cc}
\hline \hline Area & Rata - rata Temperatur Udara $\mathbf{~}^{\circ} \mathbf{C}$ ) \\
\hline Cutting plastik digital & 34.21 \\
Cutting plastik manual & 35.82 \\
Gudang barang jadi & 32.81 \\
Inspeksi & 32.97 \\
Pembuatan plastik PP besar & 35.06 \\
Pembuatan plastik PP kecil & 33.85 \\
Gudang material & 33.19 \\
Pembuatan plastik PE 1 & 33.91 \\
Pembuatan plastik PE 2 & 34.61 \\
Gudang sementara PE & 33.28 \\
\hline
\end{tabular}

Berdasarkan rata - rata temperatur udara yang diperoleh selama 6 hari pada tiap area di ruang produksi PT. Pilar Kekar Plasindo melebihi NAB yang telah ditetapkan oleh Keputusan Menteri Kesehatan Republik Indonesia Nomor 1405 / MENKES / SK / XI / 2002 tentang persyaratan kesehatan lingkungan kerja perkantoran dan industri dengan suhu yang ditentukan adalah $18-28^{\circ} \mathrm{C}$.

\section{Kesimpulan}

Berdasarkan hasil penelitian yang telah dilakukan didapatkan kesimpulan bahwa suhu ratarata di semua area pada ruang produksi PT. Pilar Kekar Plasindo melebihi NAB yang telah ditentukan oleh Keputusan Menteri Kesehatan Republik Indonesia Nomor 1405 / MENKES / SK / XI /2002 tentang persyaratan kesehatan lingkungan kerja perkantoran dan industri dengan suhu yang ditentukan adalah $18-28{ }^{\circ} \mathrm{C}$. Berdasarkan peta kontur suhu tidak terdapat zona aman di ruang produksi PT. Pilar Kekar Plasindo, karena nilai rata 29 rata temperatur udara terkecil yaitu $32,74^{\circ} \mathrm{C}$ dan nilai tersebut masih berada di atas NAB yang telah ditetapkan oleh Keputusan Menteri Kesehatan Republik Indonesia Nomor 1405 / MENKES / SK / XI / 2002. Serta, dari peta kontur yang telah dibuat dengan menggunakan software surfer 11 dapat diperoleh informasi mengenai daerah atau zona terekstrim pada tiap area ruang produksi PT. Pilar Kekar Plasindo.

\section{DAFTAR PUSTAKA}

ASHRAE. 1992. Thermal Enviromental Condition for Human Occupancy (ASHRAE Standard 55-56). Atlanta US. ASHRAE

Akimoto, T., Tanabe, S.. Yanai, T \& Sasaki, M. 2010. Thermal comfort and productivity - Evaluation of workplace environment in a task conditioned office. Building and Environment. Vol. 45 No. 1. Januari 2010. Hal 45-50

Badan Standardisasi Nasional. 2004. Standar Nasional Indonesia 16-7062-2004 Pengukuran Intensitas Penerangan di Tempat Kerja

Deb, A.K., Chowdhury, M., Hossain, Md. Israil \& Sarker, Md. Rayhan. 2018. Assessment of Noise, Temperature, Light Intensity and Their Impacts on Workers in Footwear and Leather Products Industries of Bangladesh. IOSR Journal of Environmental Science, Toxicology and Food Technology (IOSR-JESTFT). Vol 12 Issue 3 Ver. 1. Maret 2018. Hal 25-31

E. Somanathan., R. Somanathan., A. Sudarshan \& M. Tewari. 2014. The Impact of Temperature on Productivity and Labor Supply: Evidence from Indian Manufacturing. Discussion paper in Economics 14-10. November 2010

Harrianto, R. 2010. Buku Ajar Kesehatan Kerja. Jakarta. EGC Haryono \& Subaris, H. 2007. Hygiene Lingkungan Kerja (Pedoman bagi Tenaga Kesehatan di Rumah Sakit, Puskesmas, dan Instansi Lainnya serta Dosen, Mahasiswa). Jogjakarta. Mitra Cendikia

Kamif, M., Mukzam, M.D., Nurtjahjono, G.E. 2016. Pengaruh Lingkungan Kerja Terhadap Kinerja (Studi pada Karyawan Hotel Aria Gajayana Malang). Jurnal Administrasi Bisnis, Vol 38 No.1. September 2016. Hal 89-96

Kementerian Kesehatan. 2002. Keputusan Menteri Kesehatan Republik Indonesia Nomor 1405/MENKES/SK/XI/2002. Tentang Persyaratan Kesehatan Lingkungan Kerja Perkantoran dan Industri

Ningrum, N.L., Prasetya, A., Riza, M.F. 2014. Pengaruh Lingkungan Kerja Terhadap Kinerja Karyawan (Studi pada Karyawan Auto 2000 Sukun Malang). Jurnal Administrasi Bisnis, Vol 11 No.1. Juni 2014. Hal 1-9

Nurrahma, G., Suhardi, B., Astuti, R,D. 2018. Perbaikan Kondisi Iklim Kerja pada Industri XYZ, Surakarta. Proceeding SENTI UGM. Yogyakarta 17 Oktober 2018. Hal ER-60 - ER-70

Pramesti, N.Y., Suhardi, B., Astuti, R.D. 2018. Pemetaan Paparan Panas pada Bagian Produksi Boy's Cake \& Bakery dengan Software Surfer. Prosiding SNST ke-9. Fakultas Teknik Universitas Wahid Hasyim. Semarang 18 Juli 2018. Hal 113-117

Purwanto, LMF. 2006. Pengaruh Bentuk Atap Bangunan Tradisional Untuk Peningkatan Kenyamanan Termal 
Bangunan. Jurnal Dimensi Teknik Arsitektur, Vol. 34 No. 2. Desember 2006. Hal. 154-160

Sedarmayanti. 2011. Tata Kerja dan Produktivitas Kerja Suatu Tinjauan dari Aspek Ergonomi atau Kaitan antara Manusia dengan Lingkungan Kerjanya. Bandung. CV. Mandar Maju

Simanjuntak, P. J. (2003). Produktivitas Kerja Pengertian dan Ruang Lingkupnya. Jakarta. Prisma

Suhardi, B., Simanjutak, S,Y., Laksono, P,W \& Herjunowibowo, D. 2017. Work Climate and Work Load Measurement in production room of Batik Merak Manis Laweyan. AIP Conf. Proc. 1902, 020050-1020050-9. doi.org/10.1063/1.5010667.

Sukawi, Dwiyanto, A., Haryanto. 2013. Potensi Ventilasi Atap Terhadap Pendinginan Pasif Ruangan Pada
Pengembangan Rumah Sederhana (Studi Kasus di Perumnas Sendang Mulyo Semarang). Proceeding Temu Ilmiah IPLBI. Semarang 12 November 2013. Hal E-57 - E-62

Susanti, L., Aulia, N. 2013. Evaluasi Kenyamanan Termal Ruang Sekolah SMA Negeri di Kota Padang. Jurnal Optimasi Sistem Industri, Vol. 12 No. 1. Hal 310-316

Tarwaka, Bakri, S.H.A \& Sudiajeng, L. 2004. Ergonomi untuk Keselamatan, Kesehatan Kerja dan Produktivitas. Surakarta. Uniba Press.

Winata, E., Hartantyo, E. 2013. Kualitas Air Tanah di Sepanjang Kali Gajah Wong Ditinjau dari Pola Sebaran Eschericha Coli (Studi Kasus Kecamatan Umbul Harjo). Jurnal Fisika Indonesia. Vol. XVII No. 50, Agustus 2013. Hal 8-11 